the circulation. This release must also occur during many trivial infections of man, and so may explain why sera and lymphocytes from a small percentage of normal individuals have a cytotoxic effect on glial cells in vitro (Berg and Källén, 1964). One can suggest a similar explanation for the much more pronounced cytotoxic effects of lymphocytes from patients with multiple sclerosis.

We are grateful to Dr. S. J. Illavia and Miss G. E. Fairbairn for their invaluable help with the tissue cultures used in these experiments, and to Mr. E. Bowen, of the M.R.E., Porton, for the sample of antilymphocyte serum. The reports on the histological sections of the brains were kindly given to us by Dr. D. G. D. Wight, of the department of pathology, St. George's Hospital, London. The work was made possible by a generous grant from the Wellcome Trust.

\section{REFERENCES}

Allison, A. C. (1967). British Medical Bulletin, 23, 60. Berg, O., and Källén, B. (1964). Fournal of Neuropathology and Experimental

Burnet, F. M. (1968). Lancet, 2, 610.
Di George, A. M. (1965). Journal of Pediatrics, 67, 907.
East, J., De Sousa, M. A. B., Prosser, P. A., and Jaquet, H. (1967). Clinical East, J., De Sousa, M. A. B., Prosser, P. A.

Flick, J. A., and Pincus, W. B. (1963). Fournal of Experimental Medicine, $117,633$.

Holborow, E. J., and Denman, A. M. (1968). In Proceedings of the International Symposium on Gammapathies, Infections, Cancer and Immunity, ed. V. Chini, L. Bonomo, and C. Sirtori. Milan, Carlo Erba Foundation.

Illavia, S. J. (1970). The Application of Tissue Culture of the Central Nervous System to the Study of the Development of Encephalitis in Mice Following Virus Infection. Ph.D. thesis.

Illavia, S. J., and Webb, H. E. (1970). In preparation.

Martin, W. J., and Miller, J. F. A. P. (1968). Fournal of Experimental Medicine, 128, 855.

Olitsky, P. K., and Yager, R. H. (1949). Fournal of Experimental Medicine $90,213$.

Rogers, N. G., Basnight, M., Gibbs, C. J., and Gajdusek, D. C. (1967). Nature, 216, 446.

Rosenau, W., and Moon, H. D. (1961). Fournal of the National Cancer Institute, 27, 471 .

Ruddle, N. H., and Waksman, B. H. (1968). Fournal of Experimental Medicine, 128,1237

Russel, P. J., Hicks, J. D., and Burnet, F. M. (1966). Lancet, 1, 1279.

Waksman, B. H. (1959). International Archives of Allergy and Applice Immunology, 14, Suppl., p. 1.

Webb, H. E., Wight, D. G. D., Wiernik, G., Platt, G. S., and Smith, C. E. G. (1968), Fournal of Hygiene, 66, 355

Weigand, H., and Hotchin, J. (1961). Fournal of Immunology, 86, 401.

Williams, T. W., and Granger, G. A. (1968). Nature, 219, 1076.

Zlotnik, I. (1968). British fournal of Experimental Pathology, 49, 555.

\title{
Agreement Between Clinical and Radiological Diagnosis
}

\section{G. R. SUTHERLAND,* M.R.C.P.ED., F.F.R.}

\section{British Medical fournal, 1970, 4, 212-214}

\begin{abstract}
Qummary: Agreement between radiological and clinical $D$ diagnosis and the incidence of unexpected findings has been used as an indicator of the diagnostic contribution of radiology. The overall incidence of agreement was $33 \%$ - 533 out of 1,604 $x$-ray examinations. The wide variation in agreement in different radiological examinations is clearly related to the pathological nature of disease and the limitations of radiological techniques. If diagnostic radiology is to be effective its application rather than interpretation in the clinical situation must be emphasized in training programmes.
\end{abstract}

\section{Introduction}

The contribution of radiology to clinical diagnosis is not in doubt, but few attempts have been made to quantitate it outside the field of gastrointestinal disease (Cooley, 1961; Rawson, 1965; Cook, 1966). Agreement between the radiological and initial clinical diagnosis and the incidence of unexpected findings are used in this paper as indicators of the radiological diagnostic contribution. This method has obvious limitations as there is no final pathological confirmation of the diagnosis, but it has the merit of simplicity and is valid as a good approximation.

\section{Method}

All the requests for initial $x$-ray examinations of the chest, abdomen, skeletal structures, skull, and for intravenous pyelography, cholecystography and cholangiography, barium enemata and barium meal examinations were assessed during a six-week period. The following information was tabulated: (1) the department of origin of the request (medical, surgical, or other specialty-including ophthalmology, E.N.T., dermatology, obstetrics and gynaecology, paediatrics-and general

\footnotetext{
- Consultant Radiologist, Southern General Hospital, Glasgow S.W.1.
}

practitioners who have direct access to the $x$-ray department); (2) whether the radiological interpretation agreed with the clinical diagnosis as stated on the request card; (3) whether additional pathological lesions not anticipated by the clinician were observed-these were categorized as being (a) of interest or (b) of significance in terms of patient management; and (4) in cases where the clinician had clearly indicated that the examination was of a routine nature or that he anticipated a normal report and this was confirmed radiologically the request was designated "normal."

Of the 1,846 requests included in the study, 997 were from the medical department, 617 from the surgical department, and 232 from the other specialties, including 111 from general practitioners. Casualty requests were not included in the study.

In this survey the observer is heavily dependent on the accuracy of the clinical diagnosis on the original request card. Fortunately, a parallel study of follow-up requests (unpublished data) indicated that the original diagnosis was usually retained for subsequent examinations, supporting the view that it was likely to be correct in most cases.

\section{Results}

\section{"Normal" Requests}

Of 242 requests received, 223 were for chest $x$-ray examination (125 medical, 71 surgical, and 27 from other specialties). Thirteen of the remainder were "medical" and were distributed evenly among the other examinations. The proportion of "normal" to total chest $x$-ray examinations for each referring group was greatest in the surgical group and least in the medical group, an incidence of 52 and $22 \%$, respectively. The other specialties had an incidence of $38 \%$. Four of the patients who had "normal" requests were found to have a significant additional lesion (one bronchial carcinoma, one metastases from renal carcinoma, one idiopathic cardiomegaly, and one pulmonary cyst). 


\section{Clinical-radiological Agreement}

The proportions of agreement are shown in Table I. The "normal" requests have not been included as the decision to make such a request is obviously different from that when pathological change is suspected. It is apparent that there is a wide range of agreement percentage between different examinations, ranging from 1.4 for skull $x$-ray examinations to 54 for barium meals. When a single examination is considered, however, there is a general similarity in the proportion of agreement between the different referring groups. Certain variations from the trend are evident, however, and are due to the type of patient referred for investigation. For example, in the "medical" skeletal requests the agreement percentage of 56 is largely due to the preponderance of spinal $x$-ray examinations where confirmation of degenerative disease was sought. In 52 requests for $x$-ray examination of the cervical spine 34 clinical-radiological agreements occurred. Eight instances of agreement in 14 requests for examination of the remainder of the spine and 12 agreements in 31 requests for $x$-ray examination of the hands and feet were also found. In the same way in the "other specialties" group most requests (38) for abdominal $x$-ray examinations were from the obstetric department, where again there is usually a good correlation between the clinical and radiological findings.

Requests for intravenous pyelography from the surgical department show more patients referred from there with calculous or prostatic disease, which are readily diagnosed clinically and radiologically. On the other hand, medical referrals for pyelography are often concerned with the investigation of chronic pyelonephritis or hypertension in which clearly recognized radiological abnormalities are rarely found, resulting in the fewer agreements in requests from this division of the hospital. The difference in incidence of agreement between the medical and surgical divisions in the biliary examinations is unusual as there is no immediately obvious explanation for this discrepancy.

\section{Additional Lesions}

The incidence of additional lesions is shown in Table II. The skull, skeletal, and biliary examinations show a small incidence of additional findings in both categories (0.4 to $2.0 \%$ ). The remaining examinations show an incidence of between 3.5 and $6.3 \%$, but only the significant additional lesions in the barium meal group fall into this range.

The occurrence of a clinical-radiological agreement other than in the normal request group implies the detection of a lesion in the radiological examination. If the number of clinical radiological agreements is then added to the number of siginificant additional lesions the total number of significant lesions is obtained. In Table III, significant additional lesions are compared with the total number of significant abnormalities observed during the study. It is evident that more than one-fifth of all lesions detected in the chest and about one-tenth of lesions detected in the upper gastrointestinal, abdominal, and pyelographic examinations are not apparently suspected before the investigation.

\section{Discussion}

The overall incidence of agreement between radiological and clinical diagnosis in the present series, excluding normal requests, amounts to only $33 \%$ (533 of 1,604 examinations). Cook (1966), in a series of general-practitioner referrals to the Middlesex Hospital $x$-ray Department, found a similar disappointingly low proportion of lesion detection. As in the present survey, Cook observed the wide variation between different examinations. This is clearly related to the radiological characteristics of disease processes and the limita-
TABLE I.-Incidence of Clinical-radiological Agreement Excluding "Normal" Requests Related to Referring Departments

\begin{tabular}{|c|c|c|c|c|c|c|}
\hline \multirow[b]{2}{*}{ Examination } & \multicolumn{2}{|c|}{ Medical } & \multicolumn{2}{|c|}{ Surgical } & \multicolumn{2}{|c|}{ Other } \\
\hline & $\begin{array}{c}\text { Total } \\
\text { Examina- } \\
\text { tions }\end{array}$ & $\begin{array}{c}\text { No. of } \\
\text { Agree- } \\
\text { ments }\end{array}$ & $\underset{\substack{\text { Total } \\
\text { Examina- } \\
\text { tions }}}{ }$ & $\begin{array}{l}\text { No. of } \\
\text { Agree- } \\
\text { ments }\end{array}$ & $\underset{\substack{\text { Total } \\
\text { tions }}}{\text { tiomina- }}$ & $\begin{array}{l}\text { No. of } \\
\text { Agree- } \\
\text { ments }\end{array}$ \\
\hline $\begin{array}{ll}\text { Chest ... } & \ldots \\
\text { Abdoomen } & \ldots \\
\text { Skull } & \ldots \\
\text { Skeletal } & \ldots \\
\text { I.V.P. } & \ldots \\
\text { Cholecyst./ } & \end{array}$ & $\begin{array}{r}442 \\
24 \\
70 \\
97 \\
36\end{array}$ & $\begin{array}{r}145(33) \\
7 \text { ( } 1.4) \\
54(56) \\
7\end{array}$ & $\begin{array}{r}65 \\
60 \\
17 \\
104 \\
81\end{array}$ & $\begin{array}{l}20(31) \\
24(40) \\
2(49) \\
51(49) \\
32(39)\end{array}$ & $\begin{array}{r}45 \\
40 \\
6 \\
57 \\
9\end{array}$ & $\begin{aligned} 11(25) \\
19(48) \\
0 \\
20(35) \\
1\end{aligned}$ \\
\hline $\begin{array}{l}\text { Cholang. . } \\
\text { Barium Enema } \\
\text { Barium Meal }\end{array}$ & $\begin{array}{r}26 \\
42 \\
122\end{array}$ & $\begin{array}{c}7 \\
5(12) \\
59(47)\end{array}$ & $\begin{array}{l}32 \\
40 \\
43\end{array}$ & $\begin{array}{l}15 \\
7(18) \\
23(54)\end{array}$ & $\begin{array}{r}3 \\
2 \\
41\end{array}$ & $\begin{array}{c}0 \\
1 \\
22(54)\end{array}$ \\
\hline
\end{tabular}

Figures in parentheses indicate percentage of total number of examinations.

TABLE II.-Proportion of Significant and Non-significant Additional Lesion of Total Number of Examinations

\begin{tabular}{|c|c|c|c|c|c|}
\hline Examination & $\begin{array}{l}\text { Total } \\
\text { Examina- } \\
\text { tions }\end{array}$ & I.A.L. & S.A.L & $\frac{\text { I.A.L. }}{\text { Total Exam. }}$ & $\frac{\text { S.A.L. }}{\text { Total Exam. }}$ \\
\hline $\begin{array}{ll}\text { Chest . } & \ldots \\
\text { Abdomen } & \ldots \\
\text { Skull . } & \ldots \\
\text { Skeletal } & \ldots \\
\text { I.V.P. } & \ldots\end{array}$ & $\begin{array}{r}775 \\
136 \\
96 \\
260 \\
130\end{array}$ & $\begin{array}{r}44 \\
7 \\
2 \\
5 \\
8\end{array}$ & $\begin{array}{r}49 \\
5 \\
0 \\
1 \\
5\end{array}$ & $\begin{array}{l}5 \cdot 7 \\
5 \cdot 1 \\
2 \cdot 0 \\
1 \cdot 9 \\
6 \cdot 1\end{array}$ & $\begin{array}{l}6 \cdot 3 \\
3 \cdot 7 \\
0 \\
0 \cdot 4 \\
3 \cdot 9\end{array}$ \\
\hline $\begin{array}{l}\text { Cholecyst./ } \\
\text { Cholang. } \\
\text { Barium Enema . } \\
\text { Barium Meal }\end{array}$ & $\begin{array}{r}63 \\
86 \\
210\end{array}$ & $\begin{array}{l}1 \\
3 \\
4\end{array}$ & $\begin{array}{r}1 \\
3 \\
10\end{array}$ & $\begin{array}{l}1.6 \\
3.5 \\
1.9\end{array}$ & $\begin{array}{l}1.6 \\
3.5 \\
4.8\end{array}$ \\
\hline
\end{tabular}

I.A.L. $=$ Additional lesions of interest. S.A.L. $=$ Significant additional lesion.

TABLE III.-Incidence of Significant Additional Lesions Related to Total Number of Abnormalities Observed

\begin{tabular}{|c|c|c|c|c|c|c|}
\hline \multicolumn{4}{|c|}{ Examination } & $\begin{array}{c}\begin{array}{c}\text { Total } \\
\text { Abnormalities }\end{array} \\
225 \\
55\end{array}$ & $\begin{array}{c}\text { S.A.L. } \\
49 \\
5\end{array}$ & $\frac{\frac{\text { S.A.L. }}{\text { Total Abnorm. }}}{22}$ \\
\hline $\begin{array}{llr}\begin{array}{l}\text { Chest } \\
\text { Abdomen }\end{array} & \ldots & \ldots \\
\text { Skull } & \ldots & \ldots \\
\text { Skeletal } & \ldots & \ldots \\
\text { I.V.P. } & \ldots & \ldots \\
\text { Cholecyst./Cholang. } \\
\begin{array}{l}\text { Barium Enema } \\
\text { Barium Meal }\end{array} & \ldots \\
\text { Barion }\end{array}$ & $\begin{array}{l}\cdots \\
\cdots \\
\cdots \\
\cdots \\
\because \\
\cdots\end{array}$ & $\begin{array}{l}\cdots \\
\cdots \\
\cdots \\
\cdots \\
\cdots \\
\cdots \\
\cdots\end{array}$ & $\begin{array}{l}\cdots \\
\cdots \\
\cdots \\
\cdots \\
\cdots \\
\cdots\end{array}$ & $\begin{array}{r}225 \\
55 \\
3 \\
126 \\
45 \\
23 \\
16 \\
114\end{array}$ & $\begin{array}{r}49 \\
5 \\
0 \\
1 \\
5 \\
1 \\
1 \\
10 \\
\end{array}$ & $\begin{array}{r}22 \\
\frac{9}{1} \\
\frac{11}{9}\end{array}$ \\
\hline
\end{tabular}

S.A.L. $=$ Significant additional lesion.

tions of radiological methods. These problems are well known to radiologists and pathologists. Reid and Millard (1964) observed that extensive and severe pathological change was necessary before pulmonary emphysema became radiologically evident. Again, Edelstyn, Gillespie, and Grebbell (1967) showed that, mimicking the effect of a metastatic deposit, in vitro, $75 \%$ of the structure of a vertebral body had to be removed before any change was observed in the $x$-ray film. Similarly, changes in the lung due to consolidation or vascular impairment have been demonstrated by lung densitometry (Standertskjöld-Nordenstam, 1965; Sutherland, Leask, and Samuel, 1968) when no evidence of local radiological abnormality was present. On the other hand, the diagnosis of upper gastrointestinal lesions is quite precise radiologically, and an accuracy up to $90 \%$ has been claimed (Cooley, 1961; Rawson, 1965). On the other hand, in Rawson's series clinical diagnostic accuracy was only $30 \%$

Skull examinations in the present study showed the lowest incidence of clinical radiological agreement. Only one lession, a pituitary adenoma, was detected in 70 requests from the medical department; the two instances of agreement in the surgical requests related to the detection of skull fractures in patients with severe head injuries. Bull and Zilkha (1968), in a study of requests for skull $x$-ray examinations in patients attending the National Hospital, London, found a similarly low proportion of lesion detection and concluded that in patients without physical signs skull $x$-ray examinations were of limited value. These workers advocated, in the interests of economy, that in such patients a lateral film of the skull would be sufficient instead of the three or four films normally taken. 
The reasons for the low rate of lesion detection are not difficult to find. Firstly, most patients suffering from ill-defined cranial symptoms such as headache, giddiness, vertigo, alterations of consciousness or concentration, or more clearly recognizable disturbances such as epilepsy or syncope have no identifiable cause discovered in the absence of persisting physical signs. Secondly, even in those patients where a mass lesion is discovered (Bull and Zilkha, 1968) the skull $x$-ray film may remain within normal limits. This is not altogether surprising as most intracranial mass lesions will produce pronounced disturbance of function before the classical radiological signs of raised intracranial pressure or displacement of calcified midline structures are recognized. Finally, the pathological incidence of benign tumours or granulomata, for example, tuberculomata, which have undergone partial calcification and would thus be readily observed on the $x$-ray films-is so low that such a lesion is most unlikely to be found as the cause of cranial symptoms.

Though it is not possible in the present series to measure the clinical contribution to the low agreement percentages, undoubtedly it is an important factor and, unlike those inherent in radiological methods of investigation, little attention has been given to its improvement. At present the teaching of radiology to undergraduates and medical and surgical postgraduates at most centres appears largely intended to give the student a small degree of diagnostic ability. The progressive refinement of radiological methods and interpretation makes the value of this type of training increasingly doubtful. Though interesting from an educational standpoint it contributes little to the understanding of the practical application, value, and limitations of radiological investigations. If diagnostic radiology is to be used effectively then its application rather than interpretation in the clinical situation must become he main focus of attention in clinical training programmes.

\section{REFERENCES}

Bull, J. W. D., and Zilkha, K. J. (1968). British Medical fournal, 4, 569. Cook, P. L. (1966). British Medical fournal, 2, 351

Cooley, R. N. (1961). American fournal of the Medical Sciences, 242, 628 Edelstyn, G. A., Gillespie. P. J., and Grebbell, F. S. (1967). Clinical Radiology, 18, 158

Rawson, M. D. (1965). Lancet, 1, 698.

Reid, L., and Millard, F. J. C. (1964). Clinical Radiology, 15, 307.

Standertskjöld-Nordenstam, C.-G. (1965). Acta Radiologica, Suppl. No. 239.

Sutherland, G. R., Leask, E., and Samuel, E. (1968). Clinical Radiology, 19,269 .

\title{
Treatment of Menorrhagia with Tranexamic Acid. A Double-blind Trial
}

\author{
SHEI LA T. CALLENDER, ${ }^{*}$ M.D., F.R.C.P. ; G. T. WARNER, † D.PHIL. ; E. COPE, $\ddagger$ M.D., F.R.C.o.G.
}

\begin{abstract}
Summary: In a double-blind trial tranexamic acid (Cyclokapron) $1 \mathrm{~g}$. four times a day for the first four days of menstruation, significantly decreased menstrual blood loss in women with menorrhagia for which no organic cause had been found. No difference in side-effects was noted between the active and placebo treatment.
\end{abstract}

\section{Introduction}

Apart from its social inconvenience menorrhagia can cause anaemia, which may be difficult to combat even with continuous iron therapy. Hormone therapy may improve the symptom, but the recent adverse publicity given to the "pill" makes such treatment unacceptable for some. An increase in plasminogen activators in the endometrium has been found on the first day of the menstrual period in women with menorrhagia compared with those with normal menstrual loss (Rybo, 1966); the use of an antifibrinolytic agent to reduce the loss therefore seems logical. The present paper reports the results of a double-blind trial with a new antifibrinolytic agent tranexamic acid (Cyclokapron; trans-4-aminomethylcyclohexanecarboxylic acid) in the treatment of 16 women suffering from excessive menstrual loss.

\section{Patients and Methods}

The patients had either presented to the medical clinic with iron-deficiency anaemia which, from the history and other negative investigations, appeared to be due to heavy menstrual loss or they had been referred direct to the gynaecologist with a complaint of menorrhagia. Before 2dmission to the trial each had a gynaecological examination and

- First Assistant, Nuffield Department of Clinical Medicine.

+ Research Officer, Nuffield Department of Clinical Medicine.

$\$$ Consultant Obstetrician and Gynaecologist.

Radcliffe Infirmary, Oxford. dilatation and curettage was performed. If no significant clinical or histological abnormality was found the possibility of treatment with tranexamic acid was discussed with the patient and the purpose of the trial was explained fully.

Originally 20 patients agreed to take part in the investigation, but four did not complete the trial and are not included in the analysis-two elected to have a hysterectomy rather than continue with the trial, one was found to be losing blood from an undefined source between the menstruations, and one failed to return for follow-up.

Menstrual loss was measured with the Oxford total body counter (Warner and Oliver, 1966). In each case the study was started shortly after a menstrual period. About $2-4 \mu \mathrm{Ci}$ ${ }^{59} \mathrm{Fe}$ ferric citrate was given intravenously, and two weeks later the total body count was measured for the baseline value. Thereafter each patient reported for a total body count at two-weekly intervals, the activity on each occasion being related to the previous count. The blood loss between each visit was estimated by multiplying percentage loss of radioactivity by the estimated blood volume (Holt et al., 1967). The blood volume was obtained from the weight and height of the subject (Nadler et al., 1962).

For the first three menstrual periods (control blood loss) no treatment was given; over the second three menstrual periods each patient was given, at the visit before each menstruation was due, a bottle containing 32 tablets labelled $\mathrm{A}$, and she was instructed to take two tablets four times a day for the firs four days of the menstruation. She was also given a supply of sanitary pads (Dr. White's), and asked to keep a note of how many pads she used each day. For the third three months she was similarly instructed but tablets $\mathrm{A}$ were replaced by tablets B.

The tablets were either tranexamic acid $0.5 \mathrm{~g}$. per tablet or a placebo of similar size and appearance. The order of treatments was randomized, and neither the patients nor those conducting the study knew the identity of tablets A and B. A slip was attached to each bottle on which the patient recorded 